\title{
ANTIFUNGAL EFFECT OF 7-HYDROXYCITRONELLAL AGAINST $C$. TROPICALIS STRAINS: AN IN VITRO APPROACH
}

\author{
EFEITO ANTIFÚNGICO DO 7-HIDROXICITRONELAL CONTRA CEPAS DE C. \\ TROPICALIS: UMA ABORDAGEM IN VITRO
}

\author{
Abrahão Alves OLIVEIRA FILHO ${ }^{1}$; Heloísa Mara Batista Fernandes de OLIVEIRA ${ }^{2}$; \\ Cássio Ilan Soares MEDEIROS ${ }^{2 *}$; Hilzeth de Luna Freire PESSÔA ${ }^{2}$; \\ José Pinto de SIQUEIRA JÚNIOR ${ }^{2}$; Edeltrudes de Oliveira LIMA ${ }^{2}$ \\ 1. Academic Unit Biological Sciences, Federal University of Campina Grande, Paraíba, Brazil. cassioism@ hotmail.com; 2. Program in \\ Natural Products and Synthetic Bioactive, Federal University of Paraiba, Paraíba, Brazil.
}

\begin{abstract}
The fungi of the genus Candida play a relevant role in the emergence of oral infections and are increasingly more frequent the cases of infections by non-albicans strains. In light of this context and the need for new alternatives to the antimicrobial therapy, the monoterpene [7-hidroxicitronelal] (7-HO) was evaluated for its antifungal effects. For the obtainment of the MIC and MFC values the broth microdilution method was used. The MIC and the MFC of this monoterpene for $60 \%$ of the tested strains was of $256 \mu \mathrm{g} / \mathrm{mL}$ and $512 \mu \mathrm{g} / \mathrm{mL}$ respectively. Furthermore, the standard antifungal nystatin $(100 \mathrm{UI} / \mathrm{mL})$ was used as positive control for the inhibition of fungal growth. Therefore, were used 4 clinical strains of the species tropicalis (LM 06, LM 14, LM 31 and LM 36) and a standard strain (C. tropicalis ATCC 13803), originated from the Mycology collection of the Mycology Laboratory (LM) of the Health Sciences Center (CCS) of the Federal University of Paraiba (UFPB). The results obtained in this study showed fungicide activity of the compound (7-OH) against the strains of $C$. tropicalis.
\end{abstract}

KEYWORDS: Oral candidiasis. Anti-C. tropicalis. Monoterpene. 7-hidroxicitronellal.

\section{INTRODUCTION}

Oral candidiasis has been defined as an infection caused by fungi present in the microbiota of the oral cavity, Candida species are the most related to the infectious disorder. Oral candidiasis is the most common human fungal infection, is characterized by excessive growth of the Candida species in the superficial oral mucosa epithelium (MELKOUMOV et al., 2013; DHAVAN et al., 2016).

Although C. albicans is the most frequently species isolated as a colonizer pathogen of the oral mucosa, other species of Candida, such as $C$. tropicalis, C. krusei, C. glabrata, C. dubliniensis, $C$. guilliermondii, C. parapsilosis, C. kefyr, and $C$. pelliculosa, have become an importante cause of infection, mainly in immunocompromised patients and those affected by HIV (NWEZE, OGBONNAYA, 2011).

Regarding the treatment of the candidiasis, several antifungal agents of topic and systemic use are used according to the clinical picture and general state of the patient (FREIRES et al., 2016). However, due to the occurrence of undesirable factors such as the emergence of resistance to conventional antifungal drugs on the part of some strains especially in immunocompromised individuals and in general the presence of toxic effects (ZHAO et al., 2016), the study of natural products from plants with therapeutic properties, including those with antimicrobial activity has grown a lot, not only aiming to establish itself as an alternative therapeutic resource, but also due to the perspectives of isolating substances with significant efficiency and lower disadvantage rates (MISHRA et al., 2016; CHINSEMBU, 2016).

The citronellal is a monoterpene, product pf the condensation of units of $\mathrm{C} 5$ isoprene and are important components of the essential oils or aromatic plants, such as those of the genus Cymbopogon and Eucalyptus with a vast biological activity, among these antimicrobial, antioxidant, herbicide and insecticide activity (AVOSEH et al., 2015).

In light of this context, it was sought to evaluate the antifungal potential of the phytoconstituent 7-hidroxicitronellal against strains of C. tropicalis.

\section{MATERIAL AND METHODS}

\section{Phytoconstituents}

The monoterpene 7-hydroxycitronellal (Purity $\geq 95 \%$ ) was acquired from the industry (Sigma-Aldrich, São Paulo, SP). To carry out the pharmacological tests, the substance was solubilized in cremophor and diluted in distilled water. The 
concentration of the cremophor was inferior to $0.1 \%$ $\mathrm{v} / \mathrm{v}$.

\section{Inoculum}

The suspensions were prepared from recent C. tropicalis cultures, plated in sabouraud dextrose agar (SDA), and were incubated at $35 \pm 2^{\circ} \mathrm{C}$ during 24-48h. After the incubation, approximately 4-5 yeast colonies were transferred (with a sterile loop) to test tubes containing $5.0 \mathrm{~mL}$ of sterile saline solution $(\mathrm{NaCl}$ at $0.85 \%)$. The resulting suspensions were agitated during 15 seconds with the aid of a vortex machine (Fanem Ltd., Guarulhos, SP, Brazil). The turbidity of the final inoculum was normalized using a barium sulfate suspension (McFarland Standard 0.5). The final concentration obtained was of about $1-5 \times 10^{7}$ colony forming units per millimeter $(\mathrm{CFU} / \mathrm{mL})$ (KONEMAN et al., 2008).

\section{Determination of the minimum inhibitory concentration (MIC)}

Were used five strains of the tropicalis species (ATCC 13803, LM 06, LM 14, LM 31 and LM 36) from the mycology collection of the Mycology Laboratory (LM) of the Health Sciences Center (CCS) of the Federal University of Paraiba (UFPB).

The MIC of the monoterpene against the strains of $C$. tropicalis was determined by the micro-dilution technique in RPMI-1640 broth acquired from the industry (Sigma-Aldrich, São Paulo, SP). Initially, $100 \mu \mathrm{L}$ of the RPMI-1640 broth doubly concentrated was distributed in the orifices of the micro-dilution plate. Next, $100 \mu \mathrm{L}$ of the emulsion of the product was also doubly concentrated, was discharged in the wells of the first row of the plate. And by means of a serial dilution at a ratio of two concentrations of $1024-4 \mu \mathrm{g} / \mathrm{mL}$ were obtained, so that the first line of the plate has a more elevated concentration and the later, a lower concentration. Finally, $10 \mu \mathrm{L}$ of the fungal inoculum was added to the cavities of the plate, where each column refers to a fungal strain in particular.

To verify the absence of interference of the solvent (cremophor), used in the preparation of the test substance, $100 \mu \mathrm{L}$ of the RPMI-1640 broth doubly concentrated, $100 \mu \mathrm{L}$ of the cremophor and $10 \mu \mathrm{L}$ of the fungal suspensions were placed in the cavities of the plate. In addition the antifungal nystatin $(100 \mathrm{UL} / \mathrm{mL})$ was used as the standard drug.

The plated were sealed in aseptic conditions and incubated at $35 \pm 2^{\circ} \mathrm{C}$ during $24-48 \mathrm{~h}$. The MIC of the tested monoterpene was defined as the lowest concentration capable of producing visible inhibition of fungal growth in the orifices of the plates, in comparison with the controls. The test was carried out in duplicate and the results expressed by the arithmetic average of the MIC's obtained in the two tests (HADACEK, GREGER, 2000, CSLI, 2008).

\section{Determination of the minimum fungicidal concentration (MFC)}

An aliquot of $20 \mu \mathrm{L}$ from each well of the dishes corresponding to the (MIC, MIC $\times 2$ and MIC $\times 4$ ) were plated in dishes with SDA. Next, it was incubated at $35 \pm 2^{\circ} \mathrm{C}$ during $24-48 \mathrm{~h}$. The MFC was defined as the lowest concentration of the monoterpene capable of inhibiting fungal growth or allowing a growth inferior to three CFUs, thus resulting in a fungicidal activity of $99.9 \%$. (ESPINEL-INGROFF et al., 2002).

\section{RESULTS}

The results of the antifungal activity, MIC and MFC of the 7-OH for the strains of $C$. tropicalis are shown in the (Table 1 and 2), respectively. For the analysis of the results it can be seen that the monoterpene presented $\mathrm{MIC}_{60 \%}$ and $\mathrm{MFC}_{60 \%}$ the values of 256 and $512 \mu \mathrm{g} / \mathrm{mL}$ respectively.

Table 1. MIC values ( $\mu \mathrm{g} / \mathrm{mL}$ ) of 7-HO against $C$. tropicalis strains by broth microdilution.

\begin{tabular}{lcccccc}
\hline Specie fungi/substance & $\begin{array}{l}\text { C. tropicalis } \\
\text { LM 06 }\end{array}$ & $\begin{array}{l}\text { C. tropicalis } \\
\text { LM 14 }\end{array}$ & $\begin{array}{l}\text { C. tropicalis } \\
\text { LM 31 }\end{array}$ & $\begin{array}{l}\text { C. tropicalis } \\
\text { LM 36 }\end{array}$ & $\begin{array}{l}\text { C. } \text { tropicalis } \\
\text { 13803 }\end{array}$ & ATCC \\
\hline 7-HO $(1024 \mu \mathrm{g} / \mathrm{mL})$ & + & + & + & + & & + \\
$7-\mathrm{HO}(512 \mu \mathrm{g} / \mathrm{mL})$ & + & + & + & + & + \\
$7-\mathrm{HO}(256 \mu \mathrm{g} / \mathrm{mL})$ & - & + & + & + & - \\
Negative control & - & - & - & - & - \\
Positive control $(\mathrm{NY})$ & + & + & + & + & & + \\
\hline
\end{tabular}

(+) inhibition, (-) no inhibition, (NY) nystatin 
Table 2. MFC values $(\mu \mathrm{g} / \mathrm{mL})$ of 7-HO against $C$. tropicalis strains.

\begin{tabular}{lcccccc}
\hline Specie fungi/substance & $\begin{array}{l}\text { C. tropicalis } \\
\text { LM 06 }\end{array}$ & $\begin{array}{l}\text { C. tropicalis } \\
\text { LM 14 }\end{array}$ & $\begin{array}{l}\text { C. tropicalis } \\
\text { LM 31 }\end{array}$ & $\begin{array}{l}\text { C. tropicalis } \\
\text { LM 36 }\end{array}$ & $\begin{array}{l}\text { C. } \text { tropicalis } \\
\mathbf{1 3 8 0 3}\end{array}$ & ATCC \\
\hline 7-HO $(1024 \mu \mathrm{g} / \mathrm{mL})$ & + & + & + & + & & + \\
$7-\mathrm{HO}(512 \mu \mathrm{g} / \mathrm{mL})$ & - & + & - & + & - \\
7-HO $(256 \mu \mathrm{g} / \mathrm{mL})$ & - & - & - & - & - \\
Negative control & - & - & - & - & - \\
Positive control $(\mathrm{NY})$ & + & + & + & + & & + \\
\hline
\end{tabular}

(+) inhibition, (-) no inhibition, (NY) nystatin

\section{DISCUSSION}

The resident microbiota of the oral cavity is quite diversified, with more than 700 species of identified microorganisms. However, many have not yet been formal described (WILLIAMS, LEWIS, 2011). In this vast and complex microbial ecology of the human oral cavity, are at least twenty segments and approximately ninety isolated and classified species of yeasts; among these, eight species of the genus Candida were considered as being pathogenic: $C$. albicans, $C$. tropicalis, $C$. guilliermondii, C. kefyr, C. krusei, C. parapsilosis, C. viswanathii and C. glabrata (OKONKWO et al., 2012).

A promising resource for the discovery of new antifungal agents with better perspectives of less collateral effects are the natural products, in particular those isolated from medicinal plants used for the treatment of fungal infections (TEIXEIRA PINTO et al., 2015), in which the essential oils of the plants of the genus Cymbopogon and Eucalyptus are important sources of terpenes such as the citronellal which presents a vast biological activity, including antifungal activity (AVOSEH et al., 2015).
According to Sartoratto et al (2004) the results of Strong antimicrobial activity, are for MIC values between $0.05-0.50 \mathrm{mg} / \mathrm{mL}$. For moderate activity, the MIC is between $0.6-1.50 \mathrm{mg} / \mathrm{mL}$ and for weak activity; the MIC value is above $1.50 \mathrm{mg} / \mathrm{mL}$. The results of this study showed that the monoterpene 7-HO presents a strong antifungal effect against strains of $C$. tropicalis with $\mathrm{MIC}_{60 \%}$ of $256 \mu \mathrm{g} / \mathrm{mL}$. This result is in accordance with the results obtained by Trindade et al (2015) in his study using the monoterpene citronellal against several fungal strains of the genus Candida.

Analyzing the results of the MFC it can be observed that the monoterpene has fungicide activity against strains of $C$. tropicalis, as according to Hafidh et al (2011), when the ratio between the MFC/MIC is between 1 and 2, it indicates that the biological effect of the compound is fungicide and not fungistatic.

\section{CONCLUSION}

The monoterpene 7-HO has a strong antifungal effect against strains of $C$. tropicalis, having potential to become an alternative of choice for the treatment of diseases caused by this microorganism.

RESUMO: Os fungos do gênero Candida tem um papel relevante no aparecimento de infecções orais e são cada vez mais frequentes os casos de infecções por cepas não-albicans. Diante deste contexto e da necessidade de novas alternativas para a terapia antimicrobiana, o monoterpeno [7-hidroxicitronelal] (7-HO) foi avaliado pelos seus efeitos antifúngicos. Para a obtenção dos valores da CIM e da CFM foi utilizado o método da microdiluição em caldo. A CIM e a CFM deste monoterpeno para $60 \%$ das cepas testadas foram de $256 \mu \mathrm{g} / \mathrm{mL}$ e $512 \mu \mathrm{g} / \mathrm{mL}$ respectivamente. Além disso, o antifúngico padrão nistatina $(100 \mathrm{UI} / \mathrm{mL})$ foi utilizado como controle positivo para inibir o crescimento fúngico. Por tanto, foram utilizadas 4 cepas clínicas da espécie tropicalis (LM 06, LM 14, LM 31 e LM 36) e uma cepa padrão (C. tropicalis ATCC 13803), oriundas da Micoteca do Laboratório de Micologia (LM) do Centro de Ciências da Saúde (CCS) da Universidade Federal da Paraíba (UFPB). Os resultados obtidos neste estudo mostraram atividade fungicida do composto (7-OH) contra as cepas de C. tropicalis.

PALAVRAS-CHAVES: Candidíase oral, Anti-C. tropicalis, Monoterpeno, 7-hidroxicitronelal. 


\section{REFERENCES}

AVOSEH, O.; OYEDEJI, O.; RUNGQU, P.; NKEH-CHUNGAG, B.; OYEDEJI, A. Cymbopogon Species; Ethonopharmacology, Phytochemistry and the Pharmacological Importance. Molecules. v. 20, n. 5, p. 74387453, 2015. https://doi.org/10.3390/molecules20057438

CHINSEMBU, K. C. Plants and other natural products used in the management of oral infections and improvement of oral health. Acta Tropica. v. 154, n. 1, p. 6-18, 2016.

https://doi.org/10.1016/j.actatropica.2015.10.019

CLINICAL AND LABORATORY STANDARDS INSTITUTE, Reference method for broth dilution antifungal susceptibility testing of yeasts. CLSI document M27-A3, v. 28, n. 14, p. 10, 2008.

DHAVAN, A. A.; IONESCU, A. C.; KADUSKAR, R. D.; BRAMBILLA, E.; DALLAVALLE, S.; VARONI, E. M.; IRITI, M. Antibacterial and antifungal activities of 2, 3-pyrrolidinedione derivatives against oral pathogens. Bioorg. Med. Chem. Lett., v. 26, n. 5, p. 1376-1380, 2016.

https://doi.org/10.1016/j.bmcl.2016.01.082

ESPINEL-INGROFF, A.; CHATURVEDI, V.; FOTHERGILL, A.; RINALDI, M. G. Optimal testing conditions for determining MICs and minimum fungicidal concentrations of new and established antifungal agents for uncommon molds: NCCLS collaborative study. J. Clin. Microbiol., v. 40, n. 10, p. 3776-3781, 2002. https://doi.org/10.1128/JCM.40.10.3776-3781.2002

FREIRES, I. A.; QUEIROZ, V. C. P. P.; FURLETTI, V. F.; IKEGAKI, M.; ALENCAR, S. M.; DUARTE, M. C. T.; ROSALEN, P. L. Chemical composition and antifungal potential of Brazilian propolis against Candida spp. J. Med. Mycol., v. 26, n. 2, p. 122-132, 2016. https://doi.org/10.1016/j.mycmed.2016.01.003

HADACEK, F.; GREGER, H. Testing of antifungal natural products: methodologies, comparability of results and assay choice. Phytochem. Anal., v. 11, n. 2, p. 137-147, 2000. https://doi.org/10.1002/(SICI)10991565(200005/06)11:3<137::AID-PCA514>3.0.CO;2-I

HAFIDH, R. R.; ABDULAMIR, A. S.; VERN, L. S.; BAKAR, F. A.; ABAS, F.; JAHANSHIRI, F.; SEKAWI, Z. Inhibition of growth of highly resistant bacterial and fungal pathogens by a natural product. Open Microbiol. J., v. 5, n. 1, p. 96-106, 2011. https://doi.org/10.2174/1874285801105010096

KONEMAN, E. W; ALLEN, S. D.; JANDA, W. M.; SCHRECKENBERGER, P. C.; WIN, W. C. J. Diagnóstico Microbiológico. 6. ed. São Paulo: Médica e Científica Ltda, 2008. 1565 p.

MELKOUMOV, A.; GOUPIL, M.; LOUHICHI, F.; RAYMOND, M.; DE REPENTIGNY, L.; LECLAIR, G. Nystatin nanosizing enhances in vitro and in vivo antifungal activity against Candida albicans. J. Antimicrob. Chemother., v. 68, n. 9, p. 2099-2105, 2013. https://doi.org/10.1093/jac/dkt137

MISHRA, R.; TANDON, S.; RATHORE, M.; BANERJEE, M. Antimicrobial Efficacy of Probiotic and Herbal Oral Rinses against Candida albicans in Children: A Randomized Clinical Trial. Int. J. Clin. Pediatr. Dent., v. 9, n. 1, p. 25-30, 2016. https://doi.org/10.5005/jp-journals-10005-1328

NWEZE, E. I.; OGBONNAYA, U. L. "Oral Candida isolates among HIV-infected subjects in Nigeria.” J. Microbiology, Immunology and Infection. v. 44, n. 3, p. 172-177, 2011.

https://doi.org/10.1016/j.jmii.2011.01.028

OKONKWO, E. C.; ALO, M. N.; NWORIE, O.; ORJI, J. O.; AGAH, M. V. Prevalence of oral candida albicans infection in HIV sero-positive patients in Abakaliki. Am. J. Life Sci., v. 1, n. 2, p. 72-76, 2012. 
SARTORATTO, A.; MACHADO, A. L. M.; DELARMELINA, C.; FIGUEIRA, G. M.; DUARTE, M. C. T.; REHDER, V.L.G. Composition and antimicrobial activity of essential oils from aromatic plants used in Brazil. Braz. J. Microbiol. v. 35, n. 1, p. 275-280, 2004. https://doi.org/10.1590/S1517-83822004000300001

TEIXEIRA PINTO, Z.; SÁNCHEZ, F. F.; RAMOS DOS SANTOS, A.; AMARAL, A. C. F.; FERREIRA, J. L. P.; ESCALONA-ARRANZ, C.; QUEIROZ, M. M. C. Chemical composition and insecticidal activity of Cymbopogon citratus essential oil from Cuba and Brazil against housefly. Braz. J. Vet. Parasitol., v. 24, n. 1, p. 36-44, 2015. https://doi.org/10.1590/S1984-29612015006

TRINDADE, L. A.; OLIVEIRA, JÁ.; DE CASTRO, R. D.; LIMA, E. O. Inhibition of adherence of C. albicans to dental implants and cover screws by Cymbopogon nardus essential oil and citronellal. Clin. Oral Investig., v. 19, n. 9, p. 22223-22231, 2015. https://doi.org/10.1007/s00784-015-1450-3

WILLIAMS, D.; LEWIS, M. Pathogenesis and treatment of oral candidosis. J. Oral Microbiol., v. 3, n. 1, p. 111, 2011. https://doi.org/10.3402/jom.v3i0.5771

ZHAO, C.; LV, X.; FU, J.; HE, C.; HUA, H.; YAN, H. In vitro inhibitory activity of probiotic products against oral Candida species. J. Appl. Microbiol., v. 121, n. 1, p. 254-262, 2016. https://doi.org/10.1111/jam.13138 